\title{
GNRH1 Gene Product
}

National Cancer Institute

\section{Source}

National Cancer Institute. GNRH1 Gene Product. NCI Thesaurus. Code C136407.

A protein encoded by the GNRH1 gene. 